\title{
Association between environmental stress and epidermal papillomatosis of roach Rutilus rutilus
}

\author{
T. L. Korkea-aho ${ }^{1, *}$, J. M. Partanen ${ }^{1}$, V. Kiviniemi ${ }^{2}$, A. Vainikka ${ }^{3}$, J. Taskinen ${ }^{4}$ \\ ${ }^{1}$ Institute of Applied Biotechnology and ${ }^{2}$ IT Centre, Statistical and Mathematical Services, University of Kuopio, \\ PO Box 1627, 70211 Kuopio, Finland \\ ${ }^{3}$ Institute of Coastal Research, Swedish Board of Fisheries, PO Box 109, 74071 Öregrund, Sweden \\ ${ }^{4}$ Karelian Institute, Department of Ecology, University of Joensuu, PO Box 111, 80101 Joensuu, Finland
}

\begin{abstract}
We studied the association between environmental stress and epidermal papillomatosis of roach Rutilus rutilus L. in Finnish waters using a 'matched pairs' design. Populations impacted by industrial and/or sewage effluents were compared to reference populations from pristine sites. We examined both the prevalence (proportion of diseased fish) and intensity (number of scales covered by tumors) of the disease. Results of Generalized Linear Mixed Models (GLMM) indicated that the risk of papillomatosis was 7.5 times higher in males than females, and increased 1.3 times for every $10 \mathrm{~mm}$ increment in fish length. We controlled for the possible effects of fish size, sex and temporal variation through sampling procedures and statistical analyses. Mean prevalence of epidermal papillomatosis was 16.6 and $5.8 \%$ in impact and reference populations, respectively (10 population pairs; $\mathrm{n}_{\mathrm{fish}}=1714$ ). Results of GLMM suggested that the risk of being diseased was 2.7 times higher in the impact than reference populations. Thus, the prevalence of epidermal papillomatosis in roach can be used as an indicator of environmental stress. Results of Linear Mixed Models indicated no difference in the intensity of the disease between impact and reference populations ( 5 population pairs; $\mathrm{n}_{\text {fish }}=$ 73 ; mean \pm SE $10.7 \pm 1.8$ and $11.7 \pm 2.9$ scales, respectively), although prevalence was higher in impact populations in those 5 population pairs. The possible relationship between environmental stress and intensity of epidermal papillomatosis in natural roach populations remains to be demonstrated.
\end{abstract}

KEY WORDS: Environmental monitoring $\cdot$ Epizootic cutaneous papillomatosis $\cdot$ Roach $\cdot$ Disease Large lakes · Matched pairs Resale or republication not permitted without written consent of the publisher

\section{INTRODUCTION}

Stress, diseases and parasites frequently interact in natural populations and the outcome of this interaction can be complex (Lafferty 1997, Lafferty \& Kuris 1999). Environmental stress may compromise the immune system of fish (Jokinen et al. 1995, Aaltonen et al. 2000) which may lead to more severe infection by parasites and diseases (Lehtinen 1989, Khan 1990, Khan et al. 1994). Among the diseases of fish, papillomatosis appears to be frequently associated with environmental stress (Smith et al. 1989b, Harshbarger \& Clark 1990, Hayes et al. 1990, Premdas et al. 1995, Baumann et al. 1996, Mikaelian et al. 2000, Kortet et al. 2002, Pinkney et al. 2004). Results of laboratory experiments support the suggested association between papillo- matosis and environmental contamination. For example, the induction of papillomatosis by contaminants in fish seems to be treatment-dose dependent (Grizzle et al. 1981, 1984, Black 1983). Not only xenobiotics but other types of stress, such as oxygen deficiency (Mellergaard \& Nielsen 1995, 1997), crowding (Premdas \& Metcalfe 1994), salinity, temperature (Mellergaard \& Nielsen 1997, Peters \& Peters 1977, 1979) and hormonal manipulations (Premdas et al. 2001) may induce papillomatosis in fishes.

Epidermal papillomatosis appears as dermal lesions which are white, smooth, ovoid tumors on the skin, head, lips and fins of fishes (e.g. Premdas et al. 1995, Kortet et al. 2002). Virus particles have been discerned from papilloma tumors on fishes by electron micrographs (Anders \& Möller 1985, Lee \& Whitfield 1992) 
and by isolation from cell culture (Schwanz-Pfitzner 1976, Bloch et al. 1986, Sano et al. 1993). However, induction of papillomas can possibly also take place without viral infection (e.g. Grizzle et al. 1984, Smith et al. 1989a). Thus, the connection between papillomatosis and environmental stress can be produced both by the stress induced impairment of the immune system of fishes and by direct carcinogenic effects of contaminants (Sano et al. 1991, 1993 Lee \& Whitfield 1992, Baumann et al. 1996).

In the North American Great Lakes, epidermal papillomatosis has been proposed as a bioindicator of contaminated waters (Munkittrick \& Dixon 1989, Baumann 1992, Premdas et al. 1995, Baumann et al. 1996). The International Council for the Exploration of the Sea (ICES) has adopted epidermal papillomatosis in dab Limanda limanda as an indicator of environmental changes in the North Atlantic coastal areas (Bucke et al. 1996). Because new tools are required by the European Union's Water Framework Directive for determining the ecological status of lakes, we investigated the possible use of the roach-papillomatosis system in monitoring of environmental stress in Finnish waters.

In contrast to prevalence, the intensity of papillomatosis - i.e. the number and/or size of tumors per diseased fish-has been used only rarely in comparative studies of the disease (Premdas et al. 1995, Mikaelian et al. 2000). Thus, the need for more research on the relationship between environmental stress and intensity of papillomatosis in natural fish populations is obvious-especially since stress has increased the intensity of papillomatosis of fish in experimental conditions (Premdas \& Metcalfe 1994, Premdas et al. 2001).

Our preliminary results (Kortet et al. 2002) indicated a higher prevalence of epidermal papillomatosis in roach in lakes affected by human impact than in unaffected lakes in Finland. Lafferty (1997) stated that field studies on the relationship between anthropogenic impact and parasites/diseases of fishes should have adequately replicated designs that would overcome the confounding of spatial and temporal variation in the environment. Therefore, we studied further the possible impact of industrial and/or sewage effluents on the prevalence and intensity of epidermal papillomatosis in roach using a 'matched pairs' design (Lafferty 1997) with 10 impact populations, each with a spatially and temporally appropriate reference pair. Our hypothesis was that both the prevalence and intensity of papillomatosis in roach could provide a tool for measuring environmental stress in fishes in general. Roach is a common, widespread native cyprinid in both brackish and freshwater systems in Finland. The habitat characteristics of roach are well known and it is a suitable species for laboratory experimentation and field surveys, thereby fulfilling the criteria for a bioindicator species (Munkittrick \& Dixon 1989, Premdas et al. 1995).

\section{MATERIALS AND METHODS}

Fish collections and laboratory examinations. We collected a total of 1714 roach from 20 populations. The populations combined 10 matched pairs so that each impact population was influenced by industrial and/or sewage effluents and the reference population was from a practically pristine location (Fig. 1). Sources of contamination of the impact sites, dates of collection, sample sizes, prevalence and mean intensities of the disease, mean lengths and male proportions of the populations studied are given in Table 1. Roach were captured by ice-fishing (2004) and netting (2005), killed with a sharp blow on the head, and carefully transported to the laboratory. The total length of each fish was measured to the nearest $1 \mathrm{~mm}$ and sex was determined by examining the gonads. Fish body surfaces, fins and head were inspected for papillomas, both visually and by palpating by hand. We counted the number of scales the tumors covered on each fish (Vainikka et al. 2004b); this is a reliable method for evaluating the intensity of epidermal papillomatosis in roach (Korkea-aho et al. 2006).

The information of point source-loadings to impact sites was obtained mainly from the Finnish Environment Institute, Helsinki; Environmental Information System-HERTTA (www.environment.fi/default.asp? node $=14812 \& l a n=e n)$. Three pairs of populations were from River Kymijoki waterway, which discharges into the Gulf of Finland, Baltic Sea (Populations 1AB, 2AB, $3 \mathrm{AB}_{i}$ Fig. 1). Impact Population $1 \mathrm{~A}$, Lake Jyväsjärvi, is surrounded by the city of Jyväskylä (85000 inhabitants). The lake has been polluted by discharges from paper and pulp-mill industry, rubbish dumping ground near the shore, burning of waste and sewage effluents, and its sediments are rich in PCBs (Paasivirta et al. 1986). Reference Population 1B was Puolakka on Lake Päijänne. Impact Population 2A, Jauholahti on Lake lisvesi, was influenced by saw-mill and peat industries, and sewage effluents from the nearby city of Suonenjoki, (8000 inhabitants). Reference Population 2B was Lintuniemi on Lake Virmasvesi. Impact Population 3A, Tervonsalmi on Lake Rasvanki, is impacted by the aquaculture industry and sewage effluents from 2000 inhabitants; Reference Population 3B was Vuonamonniemi on Lake Nilakka.

Seven pairs of populations were collected from the River Vuoksi waterway, which flows to the Gulf of Finland (Fig. 1). Three pairs (Populations 4,5 and 6) were chosen from a large complex of interconnected lakes 


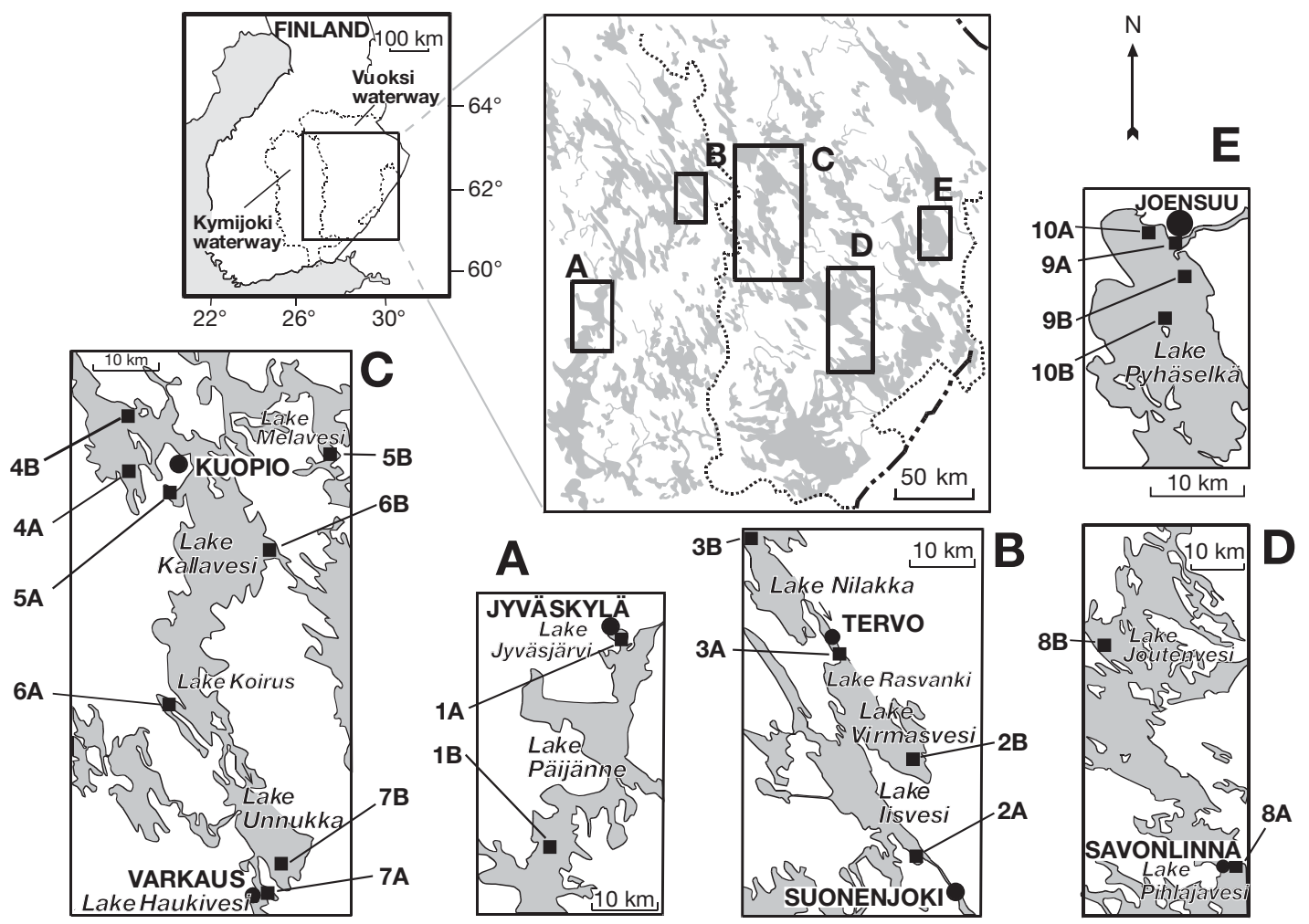

Fig. 1. Locations of Rutilus rutilus populations studied. Main waterway areas are illustrated by dotted lines. Waterflow patterns are indicated by arrows. Population details in Table 1

Table 1. Rutilus rutilus. Collections from Populations 1 to 10 used in this study. Impact: sources of contamination in impact site ( $\mathrm{F}=$ fish-farming, $\mathrm{P}=$ paper and pulp industry, $\mathrm{B}=\mathrm{PCB}, \mathrm{S}=$ sewage effluents, $\mathrm{M}=$ mining industry, $\mathrm{O}=\mathrm{Oil}$ storage, $\mathrm{C}=$ peat industry, $\mathrm{E}=$ sawmill industry, $\mathrm{D}=$ rubbish dumping site on land, $\mathrm{G}=$ snow dumping site on land, $\mathrm{T}=$ thermal effluents; Reference = reference site); Date: sampling date (dd.mm.yy); $\mathrm{n}$ : number of fish collected; Prevalence: prevalence of papillomatosis $(\%)$; Intensity: mean $\pm \mathrm{SE}$ intensity of papillomatosis; Length: mean $\pm \mathrm{SE}$ fish length $(\mathrm{mm})$; Male: proportion of male fish (\%) in population. Population pairs 1 to 10 were used to compare prevalence, Population pairs 2, 3, 4, 9 and 10 to compare intensity of papillomatosis in relation to environmental stress

\begin{tabular}{|c|c|c|c|c|c|c|c|}
\hline Population & Impact & Date & $\mathrm{n}$ & Prevalence & Intensity & Length & Male \\
\hline $1 \mathrm{~A}^{\mathrm{a}}$ & $\mathrm{P}, \mathrm{B}, \mathrm{S}$ & 30.03 .04 & 103 & 22.0 & $3.9 \pm 0.9$ & $185 \pm 1$ & 28 \\
\hline $1 \mathrm{~B}$ & Reference & 04.04 .04 & 58 & 1.7 & - & $178 \pm 3$ & 44 \\
\hline $2 \mathrm{~A}^{\mathrm{a}}$ & $\mathrm{E}, \mathrm{C}, \mathrm{S}$ & 02.04 .04 & 20 & 30.0 & $10.3 \pm 4.5$ & $198 \pm 4$ & 15 \\
\hline $2 \mathrm{~B}^{\mathrm{a}}$ & Reference & 03.04 .04 & 81 & 4.9 & $24.8 \pm 9.9$ & $180 \pm 2$ & 16 \\
\hline $3 \mathrm{~A}^{\mathrm{a}}$ & $\mathrm{F}, \mathrm{S}$ & 08.04 .04 & 72 & 9.7 & $7.0 \pm 2.1$ & $170 \pm 2$ & 52 \\
\hline $3 \mathrm{~B}^{\mathrm{a}}$ & Reference & 12.04 .04 & 78 & 9.0 & $3.7 \pm 1.5$ & $168 \pm 2$ & 30 \\
\hline $4 \mathrm{~A}^{\mathrm{a}}$ & $\mathrm{D}, \mathrm{S}$ & $17-24.3 .04$ & 244 & 10.0 & $9.6 \pm 2.0$ & $164 \pm 1$ & 22 \\
\hline $4 \mathrm{~B}$ & Reference & 04.04 .04 & 51 & 3.9 & - & $157 \pm 1$ & 18 \\
\hline $5 \mathrm{~A}^{\mathrm{a}}$ & $\mathrm{P}, \mathrm{O}, \mathrm{G}$ & $17-22.3 .04$ & 301 & 11.0 & $16.8 \pm 4.3$ & $152 \pm 1$ & 34 \\
\hline $5 \mathrm{~B}$ & Reference & 11.04 .04 & 102 & 2.0 & - & $159 \pm 1$ & 14 \\
\hline $6 \mathrm{~A}^{\mathrm{a}}$ & $\mathrm{M}, \mathrm{S}$ & $1-4.04 .04$ & 39 & 21.0 & $8.5 \pm 3.8$ & $166 \pm 2$ & 18 \\
\hline $6 B^{a}$ & Reference & 03.04 .04 & 93 & 9.7 & $18.1 \pm 5.9$ & $165 \pm 2$ & 25 \\
\hline $7 \mathrm{~A}$ & $\mathrm{P}, \mathrm{T}$ & 25.04 .04 & 82 & 2.4 & - & $159 \pm 2$ & 41 \\
\hline $7 \mathrm{~B}^{\mathrm{a}}$ & Reference & $25-26.4 .04$ & 53 & 5.7 & $3.7 \pm 1.5$ & $174 \pm 2$ & 17 \\
\hline $8 \mathrm{~A}^{\mathrm{a}}$ & $\mathrm{P}, \mathrm{S}$ & 10.04 .04 & 50 & 14.0 & $5.6 \pm 2.6$ & $178 \pm 3$ & 48 \\
\hline $8 \mathrm{~B}$ & Reference & 11.04 .04 & 58 & 4.8 & - & $170 \pm 2$ & 37 \\
\hline $9 \mathrm{~A}^{\mathrm{a}}$ & $\mathrm{P}, \mathrm{E}, \mathrm{S}$ & 17.05 .05 & 26 & 30.8 & $22.8 \pm 7.1$ & $207 \pm 5$ & 62 \\
\hline $9 \mathrm{~B}^{\mathrm{a}}$ & Reference & 17.05 .05 & 27 & 14.8 & $6.0 \pm 4.7$ & $206 \pm 2$ & 26 \\
\hline $10 \mathrm{~A}^{\mathrm{a}}$ & $\mathrm{P}, \mathrm{S}$ & 20.05 .05 & 144 & 11.8 & $7.7 \pm 2.0$ & $178 \pm 3$ & 57 \\
\hline $10 \mathrm{~B}^{\mathrm{a}}$ & Reference & 20.05 .05 & 32 & 9.4 & $1.7 \pm 0.7$ & $191 \pm 6$ & 41 \\
\hline
\end{tabular}


around the city of Kuopio all with the same water surface level. Impact Population 4A, Neulaniemi on Lake Kallavesi, was influenced by a large waste-disposal site on land; Reference Population 4B was Autioranta on Lake Kallavesi. Impact Population 5A, Siikalahti on Lake Kallavesi, was influenced by industrial discharges (a pulp-mill and oil storage), snow removal (salts and roadway pollutants) runoff, and sewage effluents from the nearby city of Kuopio (90000 inhabitants); Reference Population 5B was Melalahti on Lake Melavesi. Impact Population 6A, Haaslahti on Lake Koirus, was influenced by mining industry and sewage effluents; Reference Population 6B was Litmalahti on Lake Kallavesi.

Impact Population 7A, Huruslahti on Lake Haukivesi, was influenced by discharges and thermal effluents from a paper and pulp mill; Reference Population 7B was in Kinkamonselkä on Lake Unnukka. Impact Population 8A, Pääskyniemi on Lake Pihlajavesi, was influenced by effluents from the plywood industry and sewage effluents from the nearby city of Savonlinna (28000 inhabitants); Reference Population 8B was Ahvensalmi on Lake Joutenvesi. Impact Population 9A, Joensuu on Lake Pyhäselkä, was influenced by a paper mill, plywood mill, sawmill and sewage effluents from 60000 inhabitants (sediments contaminated by wood preservatives released by the sawmill contained high concentrations of chlorophenols, arsenic, chromium and copper at 9A: Lyytikäinen et al. 2001a); Reference Population 9B was Napaluoto on Lake Pyhäselkä. Impact Population 10A, Noljakansaaret on Lake Pyhäselkä, was near the city of Joensuu and thus received the industrial and sewage effluents of the city; Reference Population 10B was Perhesaaret on Lake Pyhäselkä.

The prevalence of papillomatosis in roach populations peaks at spawning (Kortet et al. 2002). Therefore, we collected fishes from reference populations on the same day, or a maximum of 22 (on average $5 \mathrm{~d}$ ) later than from the impact populations (Table 1).

Statistical analyses. We used Generalized Linear Mixed Models (GLMM) to study the prevalence of papillomatosis in impact and reference populations. Using the canonical link, a GLMM for the data was specified as $\log \left[\pi_{i j} /\left(1-\pi_{i j}\right)\right]=m+\beta_{i}+\theta_{j}$ where $m$ is the intercept, $\beta_{i}$ is the fixed site effect (impact, reference) and $\theta_{j}$ is the random population pair effect due to the matched pairing of sampled populations. The model is an extension of logistic regression to cases where standard model assumptions are violated, for example due to the hierarchical nature of the data. Fish size and gender has been previously shown to affect the prevalence of epidermal papillomatosis in roach (Kortet et al. 2002, 2003a). Therefore, the model was extended such that we included the fixed effects of sex and fish size in the model as covariates. The interactions between impact and sex and between impact and length were also studied by including them as fixed effects in the model. The differences in male proportions between populations (impact vs. reference) in the matched pair were analyzed by similarly applying GLMM. The differences in fish length between populations were analyzed applying Linear Mixed Models (LMM) for the continuous response variable (length) using site (impact, reference) as fixed effect and population pair as random effect in the model.

Fac intensity, we included only pairs in which the number of diseased fishes was $\geq 3$ in both populations (Population Pairs 2, 3, 6, 9 and 10; Table 1). To avoid the problem of non-normality we analyzed $\log _{10}$-transformed, individual level, intensity data. We applied LMM for comparing the differences between impact and reference populations by including site (impact, reference) as a fixed effect and population pair as a random effect in the model. Furthermore, we analyzed the differences in papillomatosis prevalence between impact and reference populations within these 5 population pairs using GLMM.

We present the results for the analyses of binary disease risk data as Odds Ratios (OR) and their 95\% confidence intervals (CI). The effect is statistically significant at the $5 \%$ level if the CI does not include 1. For continuous outcomes we represent results as marginal means and their standard errors (SE). Statistical analyses were performed using the SAS system for Windows release 8.2 (SAS Institute).

\section{RESULTS}

Prevalence in impact and reference populations varied from 10.0 to $30.8 \%$ and from 1.7 to $14.8 \%$, respectively. Prevalence of the disease was higher in the impact population than in the reference population in every pair of populations, except 7A/7B (Table 1). The mean \pm SE prevalence of papillomatosis was $16.6 \pm$ $0.7 \%$ in impact populations and $5.8 \pm 0.5 \%$ in reference populations (Fig. 2). GLMM results indicated that the risk $(95 \% \mathrm{CI})$ of fishes being diseased was 2.72 (1.82 to 4.06) times higher in impact populations than in the reference populations, the difference being statistically significant.

In addition, the GLMM results suggested that the risk of papillomatosis was 7.35 (5.08 to 10.66) times higher for males than females, the difference being statistically significant. The mean \pm SE proportion of males was $36.1 \pm 1.5$ and $30.6 \pm 1.8 \%$ in the impact and reference populations, respectively, the difference being statistically significant (GLMM, OR = 1.28 (1.02 to 1.62$)$ ). Furthermore, a $10 \mathrm{~mm}$ increase in fish length 


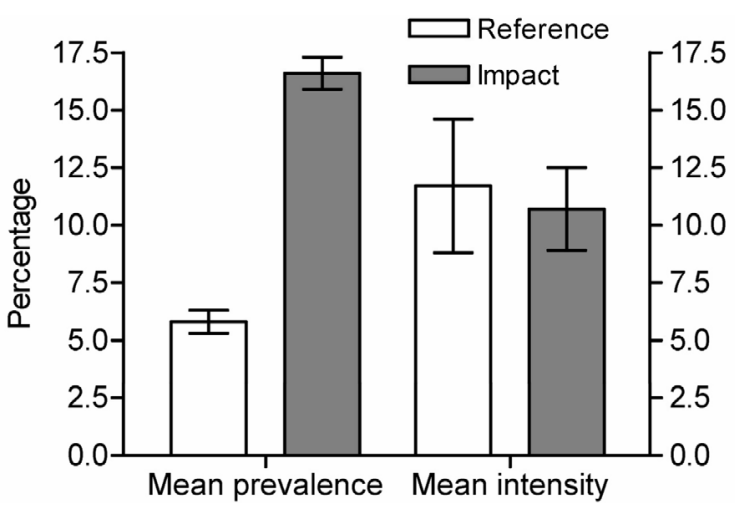

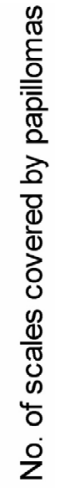

Fig. 2. Rutilus rutilus. Mean $( \pm \mathrm{SE})$ prevalence of papillomatosis in 10 reference populations and 10 impact populations and mean intensity (no. of scales covered by papillomas) of papillomatosis in 5 reference populations and 5 impact populations. Population details in Table 1

increased the risk of papillomatosis 1.31 (1.22 to 1.41) times, the increase being statistically significant. The mean $( \pm \mathrm{SE}$ ) lengths of fish from the impact and reference populations were $173.6 \pm 4.7 \mathrm{~mm}$ and $173.7 \pm 4.7$, respectively. The difference was not statistically significant $\left(\mathrm{LMM}, F_{(1,1703)}=0.01, \mathrm{df}=1703, \mathrm{p}=0.95\right)$.

When adjusted for sex and length the OR for papillomatosis in impact populations in comparison to reference populations was 2.79 (1.71-4.55) suggesting that adjustment did not alter the results. The interactions between impact and sex or between impact and length were not statistically significant (GLMM, $\mathrm{p}=0.52$ and $p=0.65$, respectively). This indicates that the effects of the covariates length and sex were consistent in impact and reference populations.

For the intensity data, impact and reference populations were not statistically significantly different with respect to the length and male proportion (LMM, $F_{(1.67)}=0.17, \mathrm{p}=0.87$ and GLMM, OR $=1.21$ (0.40 to $3.68)$, respectively). The mean ( $\pm \mathrm{SE})$ intensity of papillomatosis was approximately at the same level in impact $(10.7 \pm 1.8)$ and reference $(11.7 \pm 2.9)$ populations (Fig. 2); the difference was statistically not significant $\left(\mathrm{LMM}, F_{(1,67)}=0.31, \mathrm{p}=0.58\right)$. In comparison, the risk for papillomatosis was 2.10 (1.23 to 3.57$)$ times higher in impact populations $(15.3 \pm 2.1 \%)$ than in reference populations $(8.7 \pm 1.6 \%)$ in these 5 population pairs, the difference being statistically significant.

\section{DISCUSSION}

The risk for papillomatosis was 2.7 times higher in impact populations influenced by industrial and/or sewage effluents than in their reference populations. Reference and impact populations were from the same lake - except for 2 population pairs ( 3 and 7 ) for which water flowed from one lake (reference site) to a lake below (impact site), the source of environmental stress lying between the two. For each pair, roach were generally collected at approximately the same time from the impact and the reference populations; the few cases in which samples were collected slightly later from the reference population, should merely underestimate the effect of environmental contamination, since in roach populations disease prevalence increases towards spawning in spring (Kortet et al. 2002). The matched pairs design minimizes any temporal and geographic variation confounding the effect of environmental stress by matching both sampling time and spatial location (Lafferty 1997). Furthermore, we controlled for the variation in fish length and sex ratio-factors known to influence the prevalence and intensity of papillomatosis in roach (Kortet et al. 2002, Korkea-aho et al. 2006) - by testing possible differences between reference and impact populations in regard to these factors and, if applicable, using these variables as covariates in statistical analyses.

The results of the present study are in accordance with our preliminary results (Kortet et al. 2002), suggesting that the prevalence of epidermal papillomatosis in roach increases due to environmental stress in Finnish waters. These results, together with other field studies (Smith et al. 1989b, Hayes et al. 1990, Vethaak et al. 1992, Premdas et al. 1995, Baumann et al. 1996, Pinkney et al. 2004) indicate that the association between the prevalence of papillomatosis and environmental stress may be a frequent pattern in natural fish populations. In addition, a positive relationship between the prevalence of papillomatosis and concentrations of contaminants in fishes tissues has also been found (Vethaak et al. 1992, Premdas et al. 1995, Yang et al. 2003, Pinkney et al. 2004). Furthermore, laboratory experiments have revealed, for example, that chlorinated wastewater effluents (Grizzle et al. 1981, 1984), sediments containing polynuclear aromatic hydrocarbons (PAHs) (Black 1983) and mining waste waters (Black et al. 1982) can induce papillomatosis in fishes.

Only in Population Pair 7A/7B was the disease prevalence lower in the impact population than in the reference population. The impact site of Population 7A was subject to thermal effluents and differed from all other sites by being partly uncovered by ice during our sampling. In such conditions, roach spawn earlier than normal (Kortet et al. 2003b). The fish of Population 7A had probably spawned prior to sampling since, in contrast to fish from all other sites, most fish from Population 7A had empty gonads, although they were of mature size. High levels of reproductive and stress hormones are related to the peak in papillomatosis prevalence prior to spawning (Lee \& Whitfield 1992, 
Kortet et al. 2002, Vainikka et al. 2004a,b). Both the prevalence of papillomatosis and the levels of these hormones decrease steeply after spawning in roach (Kortet et al. 2002, Vainikka et al. 2004b). These factors may have contributed to the different result obtained for Population Pair 7A/7B.

In steady-state lake habitats, roach usually migrate only distances of a few kilometers between summer and winter habitats where they remain rather sedentary (Jepsen \& Berg 2002). Thus, it is reasonable to assume that the roach from the impact and reference populations represent separate populations as the distance between populations in the present study was at shortest $5 \mathrm{~km}$. Roach may also migrate from large inland lakes to early-warming small lakes to spawn in spring (Kestemont et al. 1999). Since none of the present lakes was a small and early-warming lake, spawning migrations are not likely to have mixed the sampled populations in this study.

Impact site Joensuu in Lake Pyhäselkä (population 9A) has been previously studied in detail for chemical contamination (Lyytikäinen et al. 2001a, b, Kostamo et al. 2004). The highest prevalence of papillomatosis within Lake Pyhäselkä was observed in Population 9A. At this site sediments are contaminated by wood preservatives released by a sawmill. The sediments contain high concentrations of chlorophenols, arsenic, chromium and copper (Lyytikäinen et al. 2001a) and are toxic (Lyytikäinen et al. 2001b). The effluents from the pulp mill affecting Population 9A has been shown to increase metabolic demands and decrease growth of rainbow trout Oncorhynchus mykiss (Mattsson et al. 2001). In addition, crucian carp Carassius carassius exposed to pulp mill effluents affecting Site 9A have higher concentrations of organic halogen compounds, resin acids and $\beta$-sitosterol in the bile compared to reference fish (Kukkonen et al. 1999). These observations within Lake Pyhäselkä are in accordance with the hypothesis that environmental stress increases the prevalence of epidermal papillomatosis.

Several, mutually nonexclusive explanations can be proposed for the observed higher prevalence of epidermal papillomatosis in populations impacted by sewage and/or industrial effluents. (1) Susceptibility to infection by papilloma-inducing viruses may have increased due to stress-induced impairment of the immune system or immunotoxic effects of contaminants. Many of the present impact sites received paper- and pulp-mill effluents (Population Pairs 2, 6, 7, 8, 9 and 10) which suppress the immune function of roach (Jokinen et al. 1995, Aaltonen et al. 2000) making them more susceptible to disease. For example, pollutant-induced immunosupression has been shown to increase susceptibility of fishes to protozoan parasites (Lehtinen 1989, Khan 1990, Khan et al. 1994).
Other extraneous variables may also have affected the immune system of the roach, e.g. malnutrition may have increased susceptibility to papillomatosis. However, Vethaak et al. (1992) did not find a relationship between condition factor, somatic liver index or somatic gonad index and papillomatosis prevalence in dab Limanda limanda, whereas papillomatosis did have an apparent relationship with a pollution gradient in their study. (2) Exposure of some roach to papilloma-inducing viruses may have increased during our study, e.g. density may have increased due to eutrophication of the impact populations. High population density can promote the transmission and persistence of the disease within a fish population (Mollison \& Levin 1995). However, no correlation between stock density and prevalence of papillomatosis was found in dab by Mellergaard \& Nielsen (1995), suggesting that differences in fishes density may not explain our results. (3) Tumor growth may have been enhanced due to hormonal and carcinogenic effects of effluents. Wood extracts, especially plant sterols, have adverse endocrine effects including altering the reproductive biology of fishes (Lehtinen et al. 1999). This may have contributed to the observed difference in the prevalence of epidermal papillomatosis between impact and reference populations since the occurrence of papillomatosis in roach is associated with high concentrations of testosterone (Kortet et al. 2003a) and sex steroid injections induce papillomas in white sucker Catostomus commersoni (Premdas et al. 2001). Moreover, we cannot rule out the possible direct genotoxic effects of industrial and/or sewage effluents as an alternative explanation for the higher disease prevalence in impact populations (Baumann 1998).

In contrast to disease prevalence, studies on the possible relationship between environmental stress and the intensity of fish papillomatosis are scarce. Premdas et al. (1995) found that at a contaminated site, multiple papillomas were more common than at the reference site in a field study on white sucker. However, in another study using the same fish species, Mikaelian et al. (2000) did not find differences in the intensity of papillomatosis in relation to contamination. In our study on Rutilus rutilus, mean disease intensity did not differ between impact and reference populations in 5 pairs of populations, while the difference in the prevalence of the disease was twice as high in impact populations. This is in line with our previous observation that prevalence and mean intensity of the disease were not correlated in 19 roach populations (Korkea-aho et al. 2006). On the other hand, under experimental conditions, concomitant changes in intensity and prevalence have been reported in fish (Premdas \& Metcalfe 1994, Premdas et al. 2001), suggesting that the intensity of papillomatosis increases with increasing preva- 
lence. The number of individuals available for intensity comparisons between impact and reference populations in the present study was low; thus, the possibility that the intensity of epidermal papillomatosis can indicate environmental stress in roach populations cannot be rejected and requires more detailed study.

To enable epidermal papillomatosis to be used as a bioindicator of environmental stress it would be beneficial to experimentally examine the influence of industrial and sewage effluents on the induction and development of epidermal papillomatosis in roach. Furthermore, future studies should assess the viral etiology of the disease in roach. Thereafter, studies on the association between epidermal papillomatosis and environmental stress should (for example) include experimental infection of healthy roach (see Premdas \& Metcalfe 1996) exposed to chemical and other types of stressors.

Acknowledgements. Our study was financed by Maj and Tor Nessling Foundation (J.T. and T.L.K.), Olvi Foundation (J.M.P.), and the Biological Interactions Graduate School of the Finnish Ministry of Education (A.V.). We thank R. Kortet, J. Kukkonen, H. Calanchini, J. C. Holmes and 2 anonymous referees for their helpful comments on the manuscript and $\mathrm{T}$. Hammar for her information on the study lakes. The assistance in roach collections of the staff of the Fish Research Unit of the University of Kuopio is appreciated.

\section{LITERATURE CITED}

Aaltonen TM, Jokinen EI, Lappivaara J, Markkula SE, Salo HM, Leppänen H, Lammi R (2000) Effects of primary- and secondary-treated bleached kraft mill effluents on the immune system and physiological parameters of roach. Aquat Toxicol 51:55-67

Anders K, Möller H (1985) Spawning papillomatosis of smelt, Osmerus eperlanus L., from the Elbe estuary. J Fish Dis 8:233-235

Baumann PC (1992) The use of tumors in wild fish to assess ecosystem health. J Aquat Ecosyst Health 1:135-142

Baumann PC (1998) Epizootics of cancer in fish associated with genotoxins in sediment and water. Mutat Res-Rev Mutat Res 411:227-233

Baumann PC, Smith IR, Metcalfe CD (1996) Linkages between chemical contaminants and tumors in benthic Great Lakes fish. J Gt Lakes Res 22:131-152

Black JJ (1983) Field and laboratory studies of environmental carcinogenesis in Niagara River fish. J Gt Lakes Res 9:326-334

Black JJ, Evans ED, Harshbarger JC, Zeigel RF (1982) Epizootic neoplasms in fishes from a lake polluted by copper mining wastes. J Natl Cancer Inst 69:915-926

Bloch B, Mellergaard S, Nielsen E (1986) Adenovirus-like particles associated with ephitelial hyperplasias in dab, Limanda limanda (L.). J Fish Dis 9:281-285

Bucke D, Vethaak D, Lang T, Mellergaard S (1996) Common diseases and parasites of fish in the North Atlantic: training guide for identification. Int Counc Explor Sea Coop Res Rep 19:1-27

Grizzle JM, Schweldler TE, Scott AL (1981) Papillomas of black bullheads, Ictalurus melas (Rafinesque), living in a chlorinated sewage pond. J Fish Dis 4:345-351

Grizzle JM, Melius P, Strength DR (1984) Papilloma on fish exposed to chlorinated wastewater effluent. J Natl Cancer Inst 73:1133-1142

Harshbarger JC, Clark JB (1990) Epizootiology of neoplasma in bony fish of North America. Sci Total Environ 94:1-32

Hayes MA, Smith IR, Rushmore TH, Crane TL, Thorn C, Kocal TE, Ferguson HW (1990) Pathogenesis of skin and liver neoplasms in white suckers from industrially polluted areas in Lake Ontario. Sci Total Environ 94:105-123

Jepsen N, Berg S (2002) The use of winter refuges by roach tagged with miniature radio transmitters. Hydrobiologia 483:167-173

Jokinen EI, Aaltonen TM, Valtonen ET (1995) Subchronic effects of pulp and paper mill effluents on the immunoglobulin synthesis of roach, Rutilus rutilus. Ecotoxicol Environ Saf 32:219-225

Kestemont P, Rinchard J, Feys V, Fostier A (1999) Spawning migrations, sexual maturity and sex steroid levels in female roach Rutilus rutilus from the River Meuse. Aquat Sci 61:111-121

Khan RA (1990) Parasitism in marine fish after chronic exposure to petroleum hydrocarbons in the laboratory and to the Exxon Valdez oil spill. Bull Environ Contam Toxicol 44:759-763

Khan RA, Barker DE, Williams-Ryan K, Hooper RG (1994) Influence of crude oil and pulp and paper mill effluent on mixed infections of Trichodina cottidarium and T. saintjohnsi (Ciliophora) parasitizing Myoxocephalus octodecemspinosus and M. scorpius. Can J Zool 72:247-251

Korkea-aho T, Vainikka A, Taskinen J (2006) Factors affecting the intensity of epidermal papillomatosis in populations of roach, Rutilus rutilus L., estimated as scale coverage. J Fish Dis 29:115-122.

Kortet R, Vainikka A, Taskinen J (2002) Epizootic cutaneous papillomatosis in roach (Rutilus rutilus): sex and size dependence, seasonal occurrence and between population differences. Dis Aquat Org 52:185-190

Kortet R, Vainikka A, Rantala MJ, Jokinen I, Taskinen J (2003a) Sexual ornamentation, androgens and papillomatosis in male roach (Rutilus rutilus). Evol Ecol Res 5: 411-419

Kortet R, Taskinen J, Sinisalo T, Jokinen I (2003b) Breedingrelated seasonal changes in immunocompetence, health State and condition of the cyprinid fish, Rutilus rutilus, L. Biol J Linn Soc 78:117-127

Kostamo A, Holmblom B, Kukkonen JVK (2004) Fate of wood extractives in wastewater treatment plants at kraft pulp mills and mechanical pulp mills. Water Res 38:927-982

Kukkonen JVK, Punta E, Koponen P, Paranko J, Leppänen $H_{\text {, }}$ Holopainen IJ, Hyvärinen H (1999) Biomarker responses by cruician carp (Carassius carassius) living in a pond of secondary treated pulp mill effluent. Water Sci Technol 40:123-130

Lafferty KD (1997) Environmental parasitology: what can parasites tell us about human impacts on the environment. Parasitol Today 13:251-255

Lafferty KD, Kuris AM (1999) How environmental stress affects the impacts of parasites. Limnol Oceanogr 44:925-931

Lee S, Whitfield PJ (1992) Virus-associated spawning papillomatosis in smelt, Osmerus eperlanus L., in the River Thames. J Fish Biol 40:503-510

Lehtinen KJ (1989) Survival, growth and disease of threespined stickleback, Gasterosteus aculeatus L., brood exposed to bleached kraft mill effluents (BKME) in mesocosms. Ann Zool Fenn 26:133-144 
Lehtinen KJ, Mattsson K, Tana J, Engström C, Lerche O, Hemming $J$ (1999) Effects of wood-related sterols on the reproduction, egg survival and off-spring of brown trout (Salmo trutta lacustris L.). Ecotoxicol Environ Saf 42:40-49

Lyytikäinen M, Sormunen A, Peräniemi S, Kukkonen JVK (2001a) Environmental fate and bioavailability of wood preservatives in freshwater sediments near an old sawmill site. Chemosphere 44:341-350

Lyytikäinen M, Sormunen A, Ristola T, Juvonen R, Kukkonen JVK (2001b) Toxicity of freshwater sediments in the vicinity of an old sawmill: application of three bioassays. Arch Environ Contam Toxicol 40:318-326

Mattsson K, Lehtinen KJ, Tana J, Härdig J, Kukkonen J, Nakarai T, Engström C (2001) Effects of pulp mill effluents and restricted diet on growth and physiology of rainbow trout (Oncorhynchus mykiss). Ecotoxicol Environ Saf 49:144-154

Mellergaard S, Nielsen E (1995) Impact of oxygen deficiency on the disease status of common dab, Limanda limanda. Dis Aquat Org 22:101-114

Mellergaard S, Nielsen E (1997) Epidemiology of lymphocystis, epidermal papilloma and skin ulcers in common dab Limanda limanda along the west coast of Denmark. Dis Aquat Org 30:151-163

Mikaelian I, de Lafontaine Y, Gagnon P, Ménard C, and 5 others (2000) Prevalence of lip neoplasms of white sucker (Catostomus commersoni) in the St. Lawrence River basin. Can J Fish Aquat Sci 57 (Suppl. 1):174-181

Mollison D, Levin SA (1995) Spatial dynamics of parasitism. In: Grenfell BT, Dobson AP (eds) Ecology of infectious diseases in natural populations. Cambridge University Press, Cambridge, p 384-398

Munkittrick KR, Dixon DG (1989) Use of white suckers (Catostomus commersoni) populations to assess the health of aquatic ecosystems exposed to low-level contaminant stress. Can J Fish Aquat Sci 46:1455-1462

Paasivirta J, Mäntykoski K, Paukku R, Piilola T, Vihonen $H_{\text {, }}$ Särkkä J, Granberg K (1986) PCB in the sediments of the Lake Jyväsjärvi. Aqua Fenn 16:17-23

Peters G, Peters N (1977) Temperature-dependent growth and regression of epidermal tumors in the European eel, Anguilla anguilla L. Arch Fischwiss 27:251-263

Peters G, Peters N (1979) The influence of salinity on growth and structure of epidermal papillomas on the European eel, Anguilla anguilla L. J Fish Dis 2:13-26

Pinkney AE, Harshbarger JC, May EB, Melancon MJ (2004) Tumor prevalence and biomarkers of exposure in brown bullhead (Ameiurus nebulosus) from Back River, Furnace Creek, and Tuckahoe River, Maryland. Arch Environ Con-

Editorial responsibility: Carl B. Schreck,

Corvallis, Oregon, USA tam Toxicol 46:492-501

Premdas PD, Metcalfe CD (1994) Regression and development of lip papillomas in white suckers (Catostomus commersoni) held in the laboratory. Environ Biol Fish 40:263-269

Premdas PD, Metcalfe CD (1996) Experimental transmission of epidermal lip papillomas in white sucker, Catostomus commersoni. Can J Fish Aquat Sci 53:1018-1029

Premdas PD, Metcalfe TL, Bailey ME, Metcalfe CD (1995) The prevalence and histological appearance of lip papillomas in white sucker (Catastomus commersoni) from two sites in central Ontario, Canada. J Great Lakes Res 21:207-218

Premdas PD, Metcalfe CD, Brown S (2001) The effects of 17 $\beta$-oestradiol, testosterone and tamofixen on the development of papillomata in Catostomus commersoni. J Fish Biol 59:1056-1069

Schwanz-Pfitzner I (1976) Further studies of eel virus (Berlin) isolated from the blood of eels (Anguilla anguilla) with skin papilloma. Prog Exp Tumor Res 20:101-107

Sano N, Moriwake M, Hondo R, Sano T (1993) Herpesvirus cyprinid: A search for viral genome in infected fish by in situ hybridization. J Fish Biol 16:495-499

Sano T, Morita N, Shima N, Akimoto M (1991) Herpesvirus cyprini: lethality and oncogenity. J Fish Dis 14:533-543

Smith IR, Baker KW, Ferguson HW, Hayes MA (1989a) Ultrastructure of Malpighian and inflammatory cells in epidermal papillomas of white suckers Catostomus commersoni. Dis Aquat Org 6:17-26

Smith IR, Ferguson HW, Hayes MA (1989b) Histopathology and prevalence of epidermal papillomas epidemic in brown bullhead, Ictalurus nebulosus (Lesueur), and white sucker, Catastomus commersoni (Lacepede), populations from Ontario, Canada. J Fish Dis 12:373-388

Vainikka A, Jokinen EI, Kortet R, Taskinen J (2004a) Genderand season-dependent relationships between testosterone, oestradiol and immune functions in wild roach. J Fish Biol 64:227-240

Vainikka A, Kortet R, Taskinen J (2004b) Epizootic cutaneous papillomatosis, cortisol and male ornamentation during and after breeding in roach Rutilus rutilus. Dis Aquat Org 60:189-195

Vethaak AD, Bucke D, Lang T, Wester PW, Jol J, Carr M (1992) Fish disease monitoring along a pollution transect: a case study using dab Limanda limanda in the German Bight. Mar Ecol Prog Ser 91:173-192

Yang X, Peterson DS, Baumann PC, Lin ELC (2003) Fish biliary PAH metabolites estimated by fixed-wavelength fluorescence as an indicator of environmental exposure and effects. J Great Lakes Res 29:116-123

Submitted: August 12, 2005; Accepted: June 22, 2006

Proofs received from author(s): August 28, 2006 